допустить. Для қататоніи упомянутые случаи длють сравнительно мало моторныхь разстройств'ь, слишцомъ мало въ нихь настиящаго “автоматическаго raptus'а»; кром'Б того слипкомь мало они производять впечатльніе спутанности. Ослабоумливлніе не достигло здысь еще высокой степени,-на лищо имьется лишь незначительное притупленіе психики.

Если Крэпелинъ и склоняется снова къ воззпьнію, что нькоторые изъ настунающихь въ преклонномь возрасты психозовъ имьють отношеніе къ dementia ptaecox, то авторь, при всемь своемъ уваженіи кь нему, не можегъ сльдовать въ этомъ отнотеніи за нимь; онъ видить въ әтомъ лишь үказаніе, что подобнаго рода случаи могуть быть связаны с'ь описанными имь выпе подь именемъ dementia tardiva. Iонятіе dementia tardiva есть понятіе чисто эмпирико-клиническое, поэтому, будучи вь состояніи связать въ одно пвлое рядь “атипическихъ» случаевъ, оно имьеть шолное право на то, гтсбы зинять въ предьдахъ клинической систематики совершенно особое мьсто.

\title{
I. Маркеловъ
}

Prof. Jendrassik. Ueber die Entstehung der Hallucination und des Wabnes Neurolog. Centralbl. igos № 23.

Литература по вопросу о нозологическомь значеніи обмановъ чувствъ довольно обширна, но большинство работь, посвященныхъ этому вопросу, страдають неясностью и неопредьиленностью. Есть три рода теорій прсисхожденія галлюцинацій и бреда: теорія первичнаго возбужденія пештра образовъ воспоминаній съ совмбстнымь ассошіативнымъ распространеніемъ патологическаго раздраженія; вторая теорія-вторичеаго возвратнаго возбужденія центра чувства объ органы (organgefuhlcentrum) и третья-теорія ограниченія ассоціацій въ окружности м бста первоначальнаго раздраженія образовъ воспоминаній. Считая эти теоріи лишь гипотезами и при томъ такими, съ которыми легко потерять реальную почву, авторь даетъ свое об ьясненіе, покоющееся на анатомо-физіологическихъ и гллинческихъ данных’ь.

На основаніи клиническихъ наблюдені й мы должны принципіально отличате оть строго ограниченныхъ, прочно ассопіи- 
рованныхъ галлюшинацій параной ть галлюцинаціи, которыя наступають при алкогольномъ или лихорадочномь бредь, острой спутанности и т. п. и котпрые не проявляють совсьмъ, или же очень мало, характера ассоціативнаго связыванія идей. Нђтъ никакого сомнбнія въ томъ, что посльднія вызваны благодаря диффузному раздраженію, которое возбуждаеть центры образовъ воспоминаній. Ближе всего къ подобнаго рода галлюпинаціям стоять сновидьнія. Сновид ьніе это-настоящія галлюшинашіи, при чем' ограниченіс ассоціашіи выражено здььсь особенно рђзко. Сновидынія довольно удовлетворительно объясняются предположеніемт, что чувствительныя кльтки образовъ воспоминанія, возбужденныя во время ссстоянія бодрствованія впечатльніями вньшняго міра, во сн'b, будучи отдылены оть этихъ вдечатльній, приходятьь въ состояніе покоя. Происхожденіе параноических'ь галлюцинацій совсьмъ иное, ихъ механизмь очень отличается оть механизма бреда и сновидьній. Въ одной, недавно опубликованный на ньмецкомь язык $b$, работь авторъ пытался поқазатл, что мекду неврастеніей и паранойей не существуеть кақихь-либо строгихь границъ; очень часто и та и другая вызывають одно и то же патологическое состояніе. Поэтому не можеть быть никакого сомньнія, что въ параной бользненнымь явленіеиъ по существу представляется не бредъ или галлюцинаціи,-это только симптомы, которые возникли въ ненормальной нервной сиcreмt, ненормальной еще задолго до появленія обмановъ чувствъ; конечно они выступаютъ на первый планъ въ картины бользни и тьмь самымь отвлекають вниманіе наблюдателя оть основного процесса. Но развь ньть никакого бреда въ самомь строгомь смысль слова, если неврастеникъ бредить бользньо сердца, ракомь и долгое время никакъ не можеть разувьрить себя, устранить этотъ бредъ? Этоть страхъ, не имьющій подъ собой основанія, становится вавязчивой мыслью. Ежедневно мы видимъ переходъ отъ наиболье легкихъ неврастеническихъ состояній къ наибопье тяжелымъ случаямъ паранойи, при чемъ содержаніе факсированной идеи, им $九$, конечно, громадное вліяніе на судьбу больного, зависить большей частью отъ простой случайности. Къ сожальнію психіатрія классифищируеть все еще болье по содержанію бреда, чьмъ по сущности бользненнаго процесса. Патогенетически одно и то же, будетъ ли $\mathbf{~ б о л ь н о г о ~ н а в я з ч и - ~}$ 
вая факсированная идея, что у него сухотка спинного мозга, или же павязчивый страхь, что унего на ногахь ныть сапогь, будеть ли у него бредъ пресльдованія или бредъ величія.

У лиць, страдаюших неврастеніей, часто бывають и галлюцинаціи. Вь самомь дыл古, что собственно говоря, представляють собого эти разнаго рода опушенія въ тьль, гды несмотря на это, нб̆ть ниқақихь соотвітствуюшихь изыннсніи. Эти парестезіи вь чувствительыхъ нервахъ аналогичны шуму въ ухь. ІІервыя проецируются вь органы тьлла, посльднніз во внышній міръ. Оба рода будуть истолковываться такъ или иначе больнымғ; первыя приводять его къ идеь бользни сердця, спинной сухотки и т. п., посльднія къ мысли о пресльдованіи. Этого рода парестезіи иногда принимають совершенно опредьленную форну-больной чувствуеть, что у него черви въ тьль, вода, слова въ ухъ.

Всь эти навязчивыя идеи и галлюцинаціи являются результатомь суччестіи вь предрасположенной кь тому нервной систем⿰. Эта суччести въ сушности идентина съ гипнотиескими суччестіями. Гиннотическія суччестивныя состолнія легко вызываются у истерическихь субъектовь и также легко исчезають. Относящіяся сюда наблюденія учать, что субьекть все время суччестіи находится въ состояніи большей или меньшей степени типноза, при чемь способность ассоціаціи сильно уменшшена При очень возбудимой и сильн ассоціирующе нервной систей не врастениковь и тараноиковъ словесныя суччестіи, напротивь, удаются съ большимь трудонь или даже совсьмь не удаются, такъ кақь подобнаго рода индивиды не погружастся въ гипнотическій сонъ и легко могугь ассониировать, пока кақоенибудь случайное ириключеніе, нсожиданное движеніе руки или какоснибудь слово не останется крьпко фиксированным въ ихт мысли. Если подобнаго рода нарушеніс ассоціаціи происходить вь чувствительной области, то у больного появляются галлюцинаціи, если же оно возникло въ двигательномь районь р ьчи, то у больного, наобороть, появляется бредъ.

Такимь образомъ пе бользненное раздраженіе, имьюшее опредыленную локализапіо, являетсл причиной бреда или галлюцинаціи, а та идея, которая прочно фиксируется на предрасположснной къ эйоу понв. Теорія, предлагаемая авторомь для 
объясненія обмановь чувствъ, вполнь гармонируетъ съ патологической основой бользни. Неврастенія, иппохондрія, паранойя и рядъ другихъ, относяшихся сгда забэльваній, обусловливаются не вньшнцми причинами (будь то цсихическія или физическія), оньे возникаютъ не въ здоровой до тьхъ поръ нервной системђ, но образуютъ группу насльдственныхъ состояній неудовлетворительнаго и недостаточнаго развитія нервной системы. Эта недостаточность, проявляюшаяся анатомически в'ь ненормальной величинt, несовершенной формь, можетъ быть несовершенной химической конституціи, неудовлевторительной изолящіи нервныхъ нльтокь и ихъ отростковъ-воть основа этого состоянія; фор. ма его зависить оть степени и оть локалиеаціи недостаточнаго развитія, случайщыя вньшнія условія оқазывають только формально направляющее воздьйствіе на ходъ бользни.

\section{Г. Маркеловг。}

Џзолированныя, церебральнныя разстройства чувствительности. Kutner. (Monatsschrift für Psychiatrie und Neurologie. Band XVII. Heft 4 ).

На основаніи 4 своихт наблюденій и литературы авторъ сначала приводитъ данныл для дифференціальнаго діагноза между органическими и истерическими церебральными разстройствами чувствительности, а затымъ-данныя для топической діагностики первыхъ.

Считая үвеличеніе разстройства въ дистальномъ нацравленіи взжнымь отличительнымь признакомъ органпескихт перебральныхъ оть истерическихь геми-и моноанэтезій Dejcrine, авторъ добавляетъ, что тамъ постоянно нарушается тактильная чувствительность, чувство положенія членовь вь пространствђ и способность јокализапіи, менье постоянно-чувство давленія и костная чувствительность, болевое-же и теипературное чувство наруппатся на конечностяхъ обыкновенно равномьрно. Безъ сомньнія, при дифферанціальномъ діагноз' сльдуеть принимать въ разсчетъ этіологію, способъ возникновенія, вліяніе внушаемости, участіе органовъ высшихъ чувствъ и т д. 